\title{
INSPECTION IN THE FIELD OF EMPLOYMENT \\ RELATIONSHIPS AND PENALTY PROVISIONS UNDER THE \\ LABOR LAW
}

\author{
Vojo Belovski \\ Faculty of law - University "Goce Delcev" -Stip, Macedonia
}

Professional Paper

doi:10.5937/jouproman5-15073

\begin{abstract}
If the primary efficacy of the projected normative order is absent, the mechanism of secondary efficacy occurs, which implies forceful realization of norms - repressive measures, i.e. coercive measures, and punitive undertakings.

In the Labor Law there is a whole Chapter (Chapter XXV) devoted to inspection supervision in the field of employment relationships. Labor inspection functions as a specialized organ of the Ministry which is responsible for the affairs in the area of labor.
\end{abstract}

A request for a control by a labor inspectorate can be instigated by $a$ worker individually, by the Trade Union and by the employer. It can also be instigated ex officio by the inspection supervision.

Concerning supervision of the legal commencement of employment the procedure for the labor inspector is as follows:

a) to find employees at the place of work of the employer who are not employed according to the law;

b) employees not registered in the mandatory social insurance;

c) shall make a decision and shall order the employer to commence employment with the persons found there or with other persons without public job announcement within 8 days;

d) to employ for an indefinite period of time;

e) the number of employees shall not be reduced within the next three months;

f) will make a proposal for settlement by issuing a payment order of misdemeanor for the person responsible or a person authorized by the employer under the Law on Misdemeanors;

g) if the employer does not accept the payment order of misdemeanor, the inspector in charge will file a request for initiating a misdemeanor procedure.

As an example of the misdemeanor provisions, a fine of 7,000 Euros in denar equivalent shall be pronounced on the employerlegal entity if:

1) if no agreement for employment has been made between the employee and the employer and the employer failed to register the employee in the Mandatory pension and Disability Insurance Fund, Health insurance and insurance in case of unemployment before the employee starts with the employment (Article 13, paragraph (1), (2) (3) and (7) of the Labor Law.

Key words: Labor Law, inspection supervision, Labor inspection

\section{INSPECTION SUPERVISION IN THE AREA OF EMPLOYMENT RELATIONSHIPS AND PENALTY PROVISIONS UNDER LABOR LAW}

The subject of this research is the inspection supervision in the area of employment with emphasis on penalty provisions of labor laws in the Republic of Macedonia, Republic of Serbia and Republic of Croatia.

The goal of the research is to determine whether the amount of penalties (violations) is the same or drastically different in the countries mentioned above in labor laws.

The first general hypothesis: the legislation (the legal framework in the Republic of Macedonia) regarding inspection supervision complies (is unified and harmonized) with the acts of the International Labour Organization and the directives of the European Union.

The second general hypothesis: the legally determined amount of penalties for violating the regulations from the area of employment relationships in the compared countries is approximately the same. 
The methodological approach is a comparative analysis of the mentioned countries in relation to the subject of research.

It is ideal, i.e. perfect for every country when its legal order is being accomplished spontaneously and without violation. The realization of the projected normative order in factual relations of legal subjects implies a self-initiative, voluntary and spontaneous behavior of the legal subjects in accordance with the legal norms. If the primary efficacy of the projected normative order is absent, the mechanism of secondary efficacy occurs, which implies forceful realization of norms - repressive measures, i.e. coercive measures, and punitive undertakings. It is then that the state acts with its instruments, laws, and enforcement authorities. In the field of the labor law the inspection supervision appears.

The authority "labor inspection" appears even in the law of France from 1841 and it refers to the work of children; this law has been repeatedly modified. Inspectors' main mission is to monitor the implementation of legislative and the regulation of the work as well as the implementation of the collective agreements and to that aim they have access to the same authorizations the police has. Their status, guaranteed with the convention no. 81 of the International Labor organization, should ensure stability in their work and their independence vis-àvis "change of Government and all external influences"1

The legal basis for the establishment of inspection in the field of employment relationships in Macedonia lies in a number of international Conventions and Recommendations by the ILO, most important of which are: Recommendation no. 5 of 1919 concerning the establishment of Public Health Services that will conduct

\footnotetext{
${ }^{1}$ Taken from Alen Supiot, (2010). Trudovo pravo, Publisher Ars Lamina DOO, 38-39.
}

inspections in factories and public services. After World War II, in 1947, the ILO adopted a Convention on labor inspection no. 81, which in Part I deals with labor inspection in industry, and its part II refers to the labor inspection in commerce, Convention no.129 on labor inspection in agriculture, as well as Recommendations no.81 and 82 on labor inspection in the field of industrial and commercial enterprises, i.e. for inspection in mining and transport companies since 1947. The listed Conventions, i.e. Recommendations are mostly implemented in our labor legislation by adopting a special Law on Labor Inspection (Off. Gazette of the Republic of Macedonia No.35 / 97 of 07.23.1997), official consolidated text of 10.05.2002 and five amendments in 2011, 2013, 2014 and 2015. An entire chapter (Chapter XXV) in the Labor Law is devoted to inspection in the area of employment relationships.

Administrative supervision in the area of labor legislation is within the competence of labor inspection as a special form of performing administrative work, and, in addition to controlling and supervising the implementation of laws, regulations and procedures of employers, it also performs control of the ${ }^{2}$ material, equipment for work, means and objects for work with the work safety standards technical supervision. The labor inspection most often functions as a specialized organ of the Ministry which is responsible for the affairs of labor. Although being a part of the Ministry of Labor, it is a relatively autonomous agency within the central government and it has its own organizational hierarchy which works according to its own program. Labor inspection act sex officio and by a request from a party.

\footnotetext{
${ }^{2}$ Pelissier, J., Supiot, A., Jeammaud, A., (2000). Droit du travail, Paris, 990.
} 
It should cooperate with the most important labor factors (trade unions, employers, other inspection authorities, tripartite bodies such as the EconomicSocial Council, the Council for Safety and Health at Work, funds, employment agency, etc.).

But let us respect the regulations in that part, pursuant to the Labor Law and try to clarify some important provisions of chapter XXV "Inspection supervision in the area of employment relationships".

\section{Supervision by the labor inspection}

An important area of relations which is regulated by the Labor Law without any doubt is the area of supervision of the implementation of positive legal norms which regulate this area-the area of employment relationships.

Based on the provisions of article 256 of this law, the subject of supervision can be clearly noticed. Namely, subjects of supervision carried out by the inspection are: "supervision of the implementation of this law (Labor Law), employment regulations and other regulations in the area of labor, collective agreements and employment agreements that regulate the rights and obligations of the employer and the employee and other agreements that designate compensation for work performed in the amount higher than the amount of minimum wage established by law shall be performed by the organ of state administration responsible for the affairs of the labor inspection.

The activities of inspection under paragraph (1) of this Article shall be performed by the labor inspector."

Actually, it is about all those regulations in the broadest sense of the word that regulate the rights and obligations of employees and employers resulting from employment.

Supervision of the implementation of the positive regulations from labor-legal field is performed by the organ of state administration in charge of labor inspection. Based on this, inspection and supervision involves an organized supervision over the implementation of all regulations in the area of labor and employment relationships. ${ }^{3}$

\section{Authorizations of the labor inspection}

A key issue for labor inspection is the question that refers to its authorizations. The legal provision is clear. Namely, its authorizations are determined based on the law and on the basis of other bylaws, of course in accordance with the law.

\footnotetext{
${ }^{3}$ The State Labour Inspectorate is a body with the capacity of a legal entity and is under the Ministry of Labour and Social Policy. The State Labour Inspectorate is managed by the Director. The Labour Inspectorate operates throughout the country through the established network of inspectors numbering 63 labour inspectors and 36 inspectors for safety and health at work. Within the national labour inspectorate, the following departments operate:

Department for Inspection of labour relations

- The Department for Inspection of Health and Safety at Work

- Department for coordination, training and administrative carrying out of solutions

- Department for Standards for Safety and Health at Work

The State Labour Inspectorate carries out inspection supervision over the implementation of the laws on:

- labour relations

- employment

- safety and health at work

- collective agreements

- employment contracts and

- other legislation regulating the rights, obligations and responsibilities of workers and employers in the field of labour relations and health and safety at work. The essence of the inspectorate's existence and of the sectors that are its integral part is to reduce the number of employed persons who are not registered in the Pension and Disability Insurance Fund, protection of rights in the field of labour relations and health and safety at work.

http://www.mtsp.gov.mk/drzaven-inspektorat-zatrud.nspx
} 
In order for the labor inspection to enforce its authority, its organizational structure and work should be based on the following important principles: first, this service to be granted the status of a civil service, second, inspectors in the office need to be permanent, third, inspectors are independent in their work, fourth, the inspection service should be efficient, fifth, its powers to be determined by law and sixth, the duty of all persons who have the status of inspectors is incompatible with other professions and functions.

With the provisions of Article 257 paragraph 2 and its decisions, the question of authorized subjects that can request inspection supervision is also resolved. As authorized entities employee, trade union and employer are exhaustively determined.

\section{Indication for the removal of violations of laws and regulations}

The provisions of Article 258 and the amendments to this Article, with the provisions of Articles 258-a and Article 259-b regulate important issues related to the authorizations of the labor inspection. In other words, it is about its supervision. Concerning supervision, the activities of the labor inspection can be: firstly preventive, secondly - fair, and thirdly repressive. The inspection acts preventively when it checks into the situations and in labor-legal relations with a particular employer. It encourages all that is orderly, efficient and in compliance with positive regulations. Corrective measures of the labor inspection are taken in those cases where there are certain shortcomings and irregularities in enforcement. For corrective measures, the inspection adopts regulations and issues orders for the removal of the detected irregularities. The measures that refer to repression are more radical. Repressive measures refer to specific sanctions for the committed offences. These measures (repressive) typically boil down to penalties (fines), or prohibition of work.
The provisions of Article 258, as can be seen from the diction of this article, is about cases where labor inspection adopts corrective measures. Corrective actions are undertaken when a violation of law is determined, or of another regulation, collective agreement, commencement of employment and other acts over the implementation of which inspection supervision is being performed. Labor inspection adopts a decision and orders the employer to adopt, i.e. to revoke an act which will remove the detected irregularities and inconsistencies. Based on the decision adopted this way, the employer has to notify the labor inspection about his actions as well as about the measures he undertook as an employer for removing the detected irregularities and other illegalities.

With the amendments on the Labor Law from 2010, Article 258-a predicts concrete cases in the labor-law relations where labor inspection can determine irregularities performed. It is about specific relations governed by Articles 19, 23, 24, 50, 70, 182, 183, 195, 214-b and 252. If in these areas of labor-law relations irregularities are determined, the labor inspection will require removal within 8 days with a decision and will deliver an invitation for education to the employer. Education is organized and conducted by the State Labor Inspectorate. Training shall be conducted on one or on more homogeneous irregularities. If the person or the employer invited to the education do not come on the specified term, the education shall be deemed as realized. In a case contrary to the above mentioned one when they attend training it shall be deemed that the person is educated in respect to the identified irregularity.

In cases when, during performing control supervision, the labor inspection determines that the irregularities have been removed, it will stop further procedure. So, it stops the process of inspection supervision. 
If the irregularities are not removed, a request for initiating misdemeanor procedure is filed to the Misdemeanor Commission.

The provisions of Article 258-b regulate the issue of reports about the performed controls. The reports are prepared periodically four times in the course of a calendar year, i.e.by the diction of law quarterly. The reports are published on the web pages of the Ministry of Labor and Social Policy and the State Labor Inspectorate.

Prohibition of carrying out operations of the employer

Article 259

(1) If the labor inspector finds persons at the place of work of the employer who are not legally employed according to the law and they are not registered in the mandatory social insurance, he will adopt a decision and order the employer to commence employment with the persons found or other persons to commence employment without public job competition within 8 days for an indefinite period of time and not to reduce the number of employees within the next three months, and will make a proposal for settlement by issuing a misdemeanor pay order to the person responsible or a person authorized by him pursuant to the Law on Misdemeanors. If the employer does not accept the payment order of misdemeanor, the inspector in charge will file a request for initiating of a misdemeanor procedure.

The procedure of the labor inspector is as follows:

a) to find persons at the place of work of the employer who are not employed in accordance with the law;

b) persons who are not registered in the mandatory social insurance;

c) adopts a decision and orders the employer to commence employment without public job competition within
8 days with the persons found or other persons;

d) to employ these persons for an indefinite period of time;

e) the number of employees shall not be reduced within the next three months;

f) will make a proposal for settlement by issuing a misdemeanor pay order to the person responsible or a person authorized by him pursuant to the Law on Misdemeanors;

g) If the employer does not accept the payment order of misdemeanor, the inspector in charge will file a request for initiating a misdemeanor procedure. $^{4}$

(2) If the employer repeats the violation from paragraph (1) of this Article within a year from the date of committing the offense, the labor inspector shall with a decision forbid work at the employer on the work premises or work space for a period of 30 days and shall submit a request for initiating a misdemeanor procedure in accordance with the law.

(5) During the prohibition for practicing profession of the employer under paragraph (2) of this Article, the employer is obliged to pay the employees a compensation of salary in the amount of at least $70 \%$ of the salary paid to the employee in the previous month as well as payment contributions, and during the prohibition the employer shall not reduce the number of employees.

Authorizations of the Public Revenue Office

Article 260

(1) The organization in charge of public revenues is obliged to inform the competent inspector of labor about the employers who have not committed calculation and payment of salaries or the minimum salary for the previous month.

${ }^{4}$ See articles 47-53 of the Law on Misdemeanor (Off. Gazette of R Mno.124/2015). 
(2) The notification under paragraph (1) of this Article shall be submitted to the labor inspector according to the seat of the employer.

The legal solutions of this article are in connection with the workers' rights to salary (earnings), i.e. with the obligation of the employer to fulfill this obligation after the month during which the employee worked finishes. For the purpose of following this worker's right, i.e. the fulfillment of the obligation for payment of salary by the employer, the law provides authorization of a separate institution. It is the public revenue institution. In our system it is the Public Revenue Office under the Ministry of Finance.

The said public revenue institution is obliged to inform the competent labor inspector about every employer not making a calculation and paying salaries, i.e. the lowest salary for the previous month. For such cases, the locally competent labor inspector is determined in accordance with the seat of the employer.

In this context the standpoint of the labor jurisprudence on the issue of delay in payment of salaries should be both emphasized and highlighted here. It is considered that a delay starts and runs on from the fifth day (not later than 15 days after the expiration of the paid period - as defined by law) of the current month for payment of salaries for the previous month.

\section{Initiating of a misdemeanor procedure} Article 261

The laborinspector shall submit a request for initiating a misdemeanor procedure if he establishes that the employer or the responsible person by violating a law or other regulations, collective agreements and agreements for employment that regulate employment relationships committed an offense.

The provisions of Article 261
regulate
misdemeanor procedure

and misdemeanor responsibility of the employer. Namely, the labor inspector has the authority to initiate, or submit a request for initiating a misdemeanor procedure. $\mathrm{He}$ realizes that authorization in those cases when it is confirmed that the employer or the responsible person by violation of law or regulations, collective agreements and commencement of employment that regulate the employment relationships committed an offense. In other words, the inspector should conclude that a misdemeanor offense is committed.

Article 261-a

If a market inspector, sanitary and health inspector and the inspector for technical inspection conclude that the employer acted contrary to Article 13 paragraph (1), (2), (3) and (7) of this Act, they shall submit a request for initiating a misdemeanor procedure . $^{5}$.

\section{Postponement of a decision}

Article 262

(1) If the Labor inspector determines that the final decision of the employer has violated the right of the employee, at the request of the employee with a decision he will postpone the enforcement of that decision until the adoption of an effective court decision if the employee filed a labor dispute.

(2) The employee referred to in paragraph (1) of this Article, can file a request to the Labor inspector within 30 days of the initiation of the labor dispute in the competent court.

(3) The final decision of labor inspection from paragraph (1) of this Article cannot be subject to administrative dispute.

The diction of Article 262 of this law and its provisions are about the employee's right to legal protection and this legal protection is requested from the labor inspector.

\footnotetext{
${ }^{5}$ In order not to burden the text, Article 13 paragraphs (1), (2), (3) и (7) of the Labor Law of the Republic of Macedonia should be read
} 
These provisions regulate the question of the postponement of the decision made by the employer by which decision a particular right of the employee is violated.

In order to realize this right, the right to postponement of the implementation of the employer's decision, the fulfillment of four conditions is required, the fulfillment of which is required to be cumulative. So, all four conditions must be met, and they are: first, there is a final decision of the employer; second, with this final decision an employee's right is violated; third, that the employee has filed a labor dispute at the competent court against the final decision of the employer; and the fourth, the employee must submit are quest to the labor inspector within 30 days from the date of initiating the labor dispute.

In the light of the above said, an explanation for the following should be given. Namely, to the notion of a decision of the employer in terms of the issue of postponement, which is determined here and with this Article, it should be added that it is each individual legal act adopted by the employer which violates the employee's right.

Therefore, it can be a decision, judgment or other act, regardless of its name.

The question of violation is important. When it comes to violation, it should be obvious. The obvious violation is that violation which is serious and rough for the employee. With a rough violation there is absolutely no doubt that the law, by-law, general regulation, collective agreement or commencement of employment has been violated. The existence of this additional requirement is a factual issue and it should be assessed in each case. Therefore, only such a violation is the condition for postponing the enforcement which should be implemented by the labor inspector. For example, a postponement cannot be asked for the individual act of the employer with which a committee is established for determining an employee's disciplinary responsibility.

In legal theory, specifically the theory of labor law, the question of whether the act of the employer with which employment is terminated may be a subject of postponement is debatable, and therefore arguable. The prevailing standpoint is that the act of terminating employment cannot be the subject of postponement. Thus, the employee has no right to require postponement for such an act, even assuming that the other conditions are met (there is an act and the act is final). Against that act there is a dispute before the court, and a request to the competent inspector within the prescribed period).

In addition to the abovementioned novelties, the following novelty deserves attention as well. Namely, against decisions of the labor inspector with which the execution of the employer's decision is postponed no administrative dispute can be initiated.

\section{Right to an appeal}

Article 263

(1)The decisions of the inspector responsible for the inspection of the implementation of the provisions of this law, adopted on the basis of Articles 258, 259 and 262 of this law, an appeal to the State Committee for deciding in an administrative procedure and a procedure from employment in the second degree, may be appealed within eight days of the decision's receipt.

(2) The appeal against the decision under Article 259 does not postpone the implementation of the decision.

The provisions of Article 263 of this law regulate the issue of legal remedies. The legislator determines the following solutions. Namely, when it comes to the decisions of the labor inspector that he adopts pursuant to his authorizations, in the cases provided for in Articles 258, 259 and 262 an appeal is allowed. 
The appeal is submitted to the State Committee for deciding in an administrative procedure and in a procedure from employment in the second degree.

The deadline for appeal is 8 days from the date of the receipt of the decision.

The filed appeal has postponed effect until the decision of the second instance body. But from this rule the legislator provides that an appeal filed against the decision under Article 259 (decision of the inspector of labor obliging the employer to arrange employment with the person found without employment, as well as the decision of the inspector of labor which forbids work at the working premises of the employer, as a more radical measure in this procedure) does not postpone its execution. ${ }^{6}$

\section{MISDEMEANOR PROVISIONS}

Introductory notes

This chapter - chapter XXVI of the Labor Law regulates the whole complex of misdemeanors, misdemeanor liability, types and amount of the fine for employers - legal entities and their responsible persons, as well as for employers who are physical persons.

It also notes a special responsibility for employers, for trade unions or associations of trade unions, for those actions and behaviors that the legislator qualifies as misdemeanors or as separate misdemeanor offenses.

Regarding the competence for imposing misdemeanor sanctions, under this chapter, as will be seen in further comment, a distinction is made between two bodies: first, the competent court and second, responsibility before the Misdemeanor Authority and its Committee which is formed by the Minister responsible for the affairs of labor.

${ }^{6}$ Belovski, V, Kadriu, O, (2011). Komentar na zakonot za rabotnite odnosi, Izdavač: Kompanija Dr Belovski -,,Društvo za intelektualni uslugi i menadžment konsalting", Skopje, 402-412.
Under Article 264 of the Labor Law:

(1) A fine in the amount of 7,000 Euros in MKD equivalent shall be imposed on the employer - legal entity for misdemeanor if:

1) there is employment agreement between the employee and the employer and the employer failed to register the employee in the Mandatory Pension and Disability Insurance Fund, Health Insurance and Insurance in Case of Unemployment before beginning of employment (Article 13, paragraphs (1), (2) (3) and (7)).

2) he does not provide conditions for the safety of life and health of the employees in accordance with the regulations for safety and health at work (Article 42);

3) he does not protect and respect the personality, dignity, and privacy of the employee and does not care about protecting the employee's personal data (Article 43, paragraphs (1) and (2) and 44, paragraphs (1), (2), (3) and (4)) and

4) he prevents or attempts to prevent the labor inspector in implementing supervision (Article 256 paragraph (1) and 257 paragraph (1)).

(2) A fine in the amount of $30 \%$ of the weighed fine for the legal entity shall be imposed for a violation from paragraph (1) of this Article to the responsible person of the entity.

(3) A fine of 700 to 1.500 euros in MKD equivalent shall be imposed for the misdemeanor from paragraph (1) of this Article, on the employer - physical person.

Article 264-a

(1) A fine of 3,000 euros in KKD equivalent will be imposed on the employer for misdemeanor if the employer does not extend the employment agreement pursuant to Article 104, paragraphs (2) and (4). 
(2) A fine in the amount of $30 \%$ of the weighed fine for the legal entity shall be imposed for the violation from paragraph (1) of this Article to the responsible person of the entity.

In the provisions of Article 264 of the Labor Law violations of the employer as a legal entity are exhaustively listed. Within this article severe offenses are determined and it provides a fine for the employer in the amount of 7.000 euros in MKD equivalent. Violations of this article are exhaustively defined in items $1-4$ of paragraph 1 of Article 264.

For the person responsible a fine is predicted in the amount of $30 \%$ of the weighed fine for the legal entity (that would be 2.100 Euros), which means for the manager or the chairman of the managing board or the executive manager, depending on the system of governance. A fine from 700 Euros to 1,500 Euros shall be imposed for a violation of paragraph 1 of Article 264 to the employer-physical person - it is meant for the sole proprietor.

The next article 265 anticipates a lower amount of fine for minor offenses, such as:

(1)A fine of 3000 Euros in MKD equivalent shall be imposed on the employer-legal entity if:

1) The employment agreement is not kept in the employer's premises where the employee works and if the employee has never received a copy of the employment agreement (Article 15 paragraphs (2) and (3));

2) concludes an employment agreement with a person under 15 years of age not having general health condition (Article 18);

3) concludes an employment agreement or provides work for young people contrary to Article 18 of this Law, or concludes an employment agreement contrary to this Law (Article 19 paragraph (1), (2) and (3));

4) concludes an employment agreement with a foreigner who does not fulfill the conditions stipulated by this or other law (Article 20);

5) the employer makes changes in the employment agreement contrary to this Law (Article 28 paragraphs (2), (3) and (4));

6) does not introduce the employee with the measures for employee's safety and health at work and does not train the employee for their application, in accordance with regulations on safety and health at work (Article 32);

7) instructs the employee who works part-time to work longer than the agreed time (Articles 48 and 60); and others.

The next article 265 -a provides even lower fines. For example:

(1) A fine of 1,000 euros in MKD equivalent shall be imposed on the employer - legal entity if:

1) he does not meet the prescribed and agreed conditions for work performance determined by law, collective agreement, employer's act, i.e. requested by the employer (article 19);

2) he does not submit a copy of an employment agreement for performing work at home to the Labor inspector (article 50);

3) the employer attempts to accomplish or realize banned supervision over the trade union (Article 195);

4) he does not issue a certificate with a list or he issues a certificate with a list with incomplete data on the employees trade union members who pay dues (Article 213-c);

5) he puts an employee who organized or participated in a strike organized in accordance with the law, at a disadvantage compared to other employees (Article 239); and other.

Furthermore, Article 266 predicts the following fines: 
(1) A fine in the amount of EUR 1,200 in MKD equivalent shall be imposed for a misdemeanor of the Trade Union or association of trade unions and employers if:

1) the trade union or association of trade unions and employers within 30 days from the occurrence of change does not report the change of the trade union's name and its associations at higher levels, seat, area of activity, name of the bodies, persons authorized for advocacy, termination of activities, or authorizations in legal transactions (Article 193);

2) the trade union, or association of trade unions and employers, does not publish the collective agreement in the prescribed manner (Article 232);

3) the trade union, or association of trade unions and employers, when they are obliged to, refuse to participate in the conciliation procedure provided for in this Law (Articles 182 and 183);

4) the trade union, or association of trade unions, does not announce strike (Article 236);

5) the trade union, or association of trade unions, start a strike prior to the conciliation procedure provided for in this Law, or prior to commencing another procedure for a peaceful resolution of the dispute (Article 236 (3));

6) the trade union, or association of trade unions, in the Announcement Of Strike does not state the reasons for the strike, the place, date and time of the strike (Article 236 paragraph (5));

(2) the competent authority to impose misdemeanor sanctions under paragraph (1) of this Article is the competent court.

Misdemeanor authority

Article 266-a

(1) For offenses determined in Articles 264, 264 and 265 and 265-a of this Law, a misdemeanor procedure is led by and sanctions are imposed by the organ of the state administration responsible for the affairs of labor (hereinafter: Misdemeanor Authority).

(2) For offenses determined in Article 264 paragraph (1) item 1), paragraph (2) and (3) of this Law, a misdemeanor procedure and sanctions are imposed by the misdemeanor body in the organ of the state administration responsible for the affairs of the economy, health care and technical matters.

(3) The misdemeanor procedure referred to in paragraph (1) of this Article, before the misdemeanor body is conducted by the Committee for misdemeanor (hereinafter: Misdemeanor Committee).

(4) The Misdemeanor Committee decides on the offenses specified in this or other laws and sentences misdemeanor sanctions determined in this Law or another law.

(5) Against the decision for the misdemeanor brought by the Misdemeanor authority an appeal can be filed to the State committee for deciding in second instance in the area of inspection supervision and misdemeanor proceedings.

Establishment and operation of Misdemeanor Committee

Settlement

Article 266-c

(1) For violations of Articles 264, 264, 265 and 265-a of this Law from Article 261 of this Law, and from Article 261-a of this Law for an offense specified in Article 264 paragraph (1) item 1), paragraph (2) and (3) of this Law, before submitting a request for initiating a misdemeanor procedure, the inspector is obliged to issue a misdemeanor pay order to the person responsible or the person authorized by him in accordance with the Law on misdemeanors. 
(2) If the offender agrees to the settlement procedure, the inspector from Articles 261 and 261-a of this Law shall prepare minutes and issues a misdemeanor pay order to the responsible person or a person authorized by the employer.

(3) The minutes and the pay order shall be signed by the inspector from Articles 261 and 261-a of this law and the misdemeanor offender. By signing the receipt of the misdemeanor pay order it is considered that the offender agrees to pay the fine within eight days from the receipt of the pay order at the expense of the authority designated in the pay order.

(4) If the offender is a legal entity, the minutes and the misdemeanor pay order shall be signed by the responsible person or by a person authorized by him.

(5) The offender who pays the fine within the period specified in paragraph (3) of this article shall only pay half of the determined fine.

(6) If the offender fails to pay the fine within the period specified in paragraph (3) of this Article, the inspector from Articles 261 and 261-a of this Law shall file a request to the misdemeanor body for initiating a misdemeanor procedure.

Titles before Article 266- $\Gamma$ and Article $266-\Gamma$ are deleted

The provisions of Article 266 exhaustively define and determine the possible misdemeanors committed by a trade union or association of trade unions, on one hand and the employer on the other.

\footnotetext{
What represents a special and important novelty concerns the competence of the body that is responsible for the committed misdemeanor. Namely, for the misdemeanors sanctioned by the provisions of Article 266 the court is competent. So, persons are accountable before the competent court.
}

The provisions of Article 266-Г determine the competence of a particular body for misdemeanors sanctioned and they are exhaustively listed in Articles 264 and 264, Article 265 and Article 265-a. For these misdemeanors people are accountable to the organ of the state administration responsible for the affairs of labor. This authority is the Misdemeanor Authority. The misdemeanor procedure before the said authority is conducted by the Misdemeanor Committee. Against the decision on the misdemeanor which was brought by the Misdemeanor authority an appeal can be filed to the State Committee for deciding in second instance in the field of inspection and misdemeanor proceedings.

Bearing in mind the fact that for the majority of misdemeanors stipulated in the provisions of Articles 264, 265 and 265-A, the procedure is conducted before the Misdemeanor organ and the Misdemeanor Committee, it is no coincidence that the provisions of Article 266-b in a very clear and appropriate manner regulate the establishment of the Misdemeanor Committee, its structure, competence and procedure for keeping and imposing a sanction. The Committee has a chairman and two members. The chairman is a graduate lawyer who passed the bar exam. The Committee is formed by the Minister responsible for the affairs of labor. The mandate of the Committee is three years with the right of re-election. The Committee decides on sessions. Decisions are adopted by the majority of votes. The competent minister adopts rules of procedure for its operation

Important news is contained in Article 266-c. Namely, the provisions of this article introduce an important institution in legal proceedings and misdemeanor liability. It is =the institution of settlement. Before filing a request for misdemeanor responsibility, the state labor inspector shall propose a settlement procedure to the offender. 
If the offender agrees to a settlement, minutes are composed. The minutes, along with the pay order are signed by the inspector and the offender. By signing the receipt of the pay order it is considered that the offender agrees to pay the fine within 8 days of receipt of the pay order. If the offender acts on the pay order, he will pay half of the determined the fine. Otherwise, meaning if the offender fails to pay the fine, the state inspector will submit a request for initiating misdemeanor procedure to the Misdemeanor body.

Let us try and make a comparative analysis of some of the misdemeanor provisions, in particular of the amount of the fines - fines in the labor laws of the Republic of Croatia and the Republic of Serbia, with those stipulated in the Labor Law of the Republic of Macedonia.

For example, the Labor Law of the Republic of Macedonia stipulates:

\section{Article 264}

(1) A fine in the amount of 7,000 Euros in MKD equivalent shall be imposed on the employer - legal entity if:

1) there is no employment agreement between the employee and the employer and the employer failed to register the employee in the Mandatory pension and Disability Insurance Fund, Health insurance and insurance in case of unemployment before the beginning of employment (Article 13, paragraph (1), (2) (3) and (7)) of the Labor Law.

2) does not provide conditions for the safety of life and health of the employees in accordance with the regulations for safety and health at work (Article 42);

3) does not protect and respect the personality, dignity, and privacy of the employee and does not care about protecting the employee's personal data (Article 43, paragraphs (1) and (2) and 44 paragraphs (1), (2), (3) and (4)) and

4) prevents or attempts to prevent the Labor inspector in conducting supervision (Article 256 paragraph (1) and 257 paragraph (1)).
(2) A fine in the amount of $30 \%$ of the weighed fine for the legal entity shall be imposed for a violation of paragraph (1) of this Article to the responsible person of the entity.

(3) A fine of 700 to 1.500 euros in MKD equivalent will be imposed on the employer - physical person for the misdemeanor from paragraph (1) of this Article.

\section{Article 265}

(1)A fine of 3000 Euros in MKD equivalent value shall be imposed on the employer-legal entity, if:

10. the employer did not pay salary and salary contributions (Articles 105-114);

11) ordered the employee to work longer than the hours determined by law, does not keep or incorrectly keeps record of working hours and overtime and did not inform the inspector about the introduction of overtime work (Articles 116, 117, 119 and 120);

14) the employer does not provide a break for the employee during the working hours, rest periods between two consecutive days, weekly and annual leave in accordance with this law and does not issue a decision on annual leave (Articles 132 do156);

16) to employees that have not yet reached the age of 18 the employer does not provide protection in accordance with this Law (Articles 172 to 176);

According to the Labor Act of the Republic of Croatia from 2014 the section Most serious offences by employers stipulates:

Article 229.

(1) A fine in an amount ranging from HRK 61,000.00 to $100,000.00$ (about 8.200 to 13.400 euros) shall be imposed on the employer who is a legal person for:

1) failing to keep records on workers and working time or for failing to keep records in a stipulated manner, or for failing to deliver information on workers and working time upon labor inspector's request (Article 5), 
3) failing to deliver to the worker a letter of engagement prior to the start of employment, where the employer fails to conclude a written employment contract with the worker, or for failing to deliver to the worker a copy of the application for mandatory pension and health insurance within the stipulated deadline (Article 14, paragraphs 3 and 5),

7) employing a minor for works likely to harm his safety, health, morals or development (Article 21, paragraph 1),

13) concluding a full-time employment contract in which the duration of working time is longer than permitted by law (Article 61, paragraph 1),

24) allowing work by minors for a period exceeding 8 hours in a 24-hour period (Article 68, paragraph 1),

28) requesting, contrary to the provisions of this Act, night work by minors or for failing to ensure that the night work by minors is performed under the surveillance of an adult (Article 70, paragraphs 1 and 2),

33) concluding an agreement with the worker under which a worker waives his entitlement to annual leave in return for compensation (Article 80).

According to the Labor Law of the Republic of Serbia (Official Gazette of RS no. 24/2005, 61/2005, 54/2009. 32/2013 и 75/2014), section XXII Penal Provisions stipulates:

\section{Article 273}

A fine of 800,000 to $2,000,000$ dinars (about 6,500 to 16,200 euros) shall be imposed on the employer as a legal entity:

1) If the employer has not concluded an employment agreement or other agreement under this law with a person who works (Art.30 - 33 and Art. 197 - 202);

2) if the employer has not paid salary or minimum wage (Art. 104 and 111);

7) if it prevents the labor inspector during the inspection, or otherwise makes it impossible for him to perform the inspection (Art. 268a and 268b);

\section{Article 274}

A fine of 600,000 to $1,500,000$ dinars (about 4,800 to 12,000 euros) shall be imposed on the employer as a legal entity: 1) if the employer violates the prohibition of discrimination under this Law (Art. 1821);

2) If the employer establishes a working relationship with a person under 18 years of age contrary to the provisions of this Law (Article 25);

3) If the employer orders an employee to work overtime contrary to the provisions of this Law (Article 53);

4) if the employer made a redistribution of working time contrary to the provisions of this Law (Art. 57 and 60);

5 ) if the employer does not provide an employee who works at night with the possibility to perform work during the day contrary to the provisions of this Law (Article 62);

6) if the employer does not ensure the possibility of changing shifts to the employee who works in shifts contrary to the provisions of this Law (Article 63);

7 ) if the employer orders an employee under 18 years of age to work at contrary to the provisions of this Law (Art. 84, 87 and 88);

8) if the employer orders an employee aged between 18 and 21 years of age to work contrary to the provisions of this Law (Article 85);

9) If the employer does not provide the protection of maternity and the right to child care and special care for a child or other person in accordance with the provisions of this Law (Art. 89 - 100);

10) if the employer does not pay compensation of salary to the employee in accordance with the provisions of this Law (Art. 114-117);

11) if the employer denies employment rights contrary to the provisions of this Law (Article 147); 
12) if the employer makes a decision on suspension of the employee contrary to the provisions of this Law or if he suspends the employee from work longer than the period prescribed by the law (Art. 165169);

13) if the employer offers the employee an annex to the agreement contrary to the provisions of this Law (Art. 171-174);

14) If by the date of termination of employment, the employer fails to make payment of due wages, salaries and other earnings to the employee (Article 186);

$15)$ if the employer decides on an individual right, obligation or liability of the employee, but does not make a decision or does deliver it to the employee in accordance with the provisions of this Law (Article 193).

\section{Article 275}

A fine ranging from 400,000 (about 3,250 euros) to 1,000,000 dinars (about 8,130 euros) shall be imposed on the employer as a legal entity:

1) if the employer holds accountable the employees' representative who is acting in accordance with the law and the collective agreement (Article 13);

2 ) if the employer does not submit a copy of the employment agreement to the employee in accordance with the provisions of this Law (Article 30, paragraph 4);

3 ) if the employer acts contrary to the provisions of this law governing annual leave (Art. 68-75);

4) if an employee who has exercised the right to suspension of employment is denied the right to return to work (Article 79);

5) if an employee is not paid the compensation for expenses or other remuneration in accordance with the provisions of this law (Art. 118-120).

\section{Article 276}

A fine of 100,000 (about 80 euros) dinars shall be imposed on the employer as a legal entity, and an entrepreneur with a fine of 50,000 dinars (about 400 euros):
1) if the employer fails to keep a specimen of the agreement or a copy of the agreement in accordance with the provisions of this Law (Article 35);

2) if the employer does not ensure time for a break during work, daily and weekly rest in accordance with the provisions of this law (Art. 64 to 67);

3 ) if the employer does not approve the use of paid leave to the employee in accordance with the provisions of this Law (Article 77);

4) if the employer does not keep monthly records of earnings and compensation of earnings in accordance with the provisions of this Law (Article 122);

5) If the employer denies the employee the right to severance pay in accordance with the provisions of this Law (Article 158);

6) If the employer denies the employee the right to a period of notice, or compensation of earnings in accordance with this Law (Article 189);

7) if the employer does not return a properly completed employment record book to the employee (Article 204).

A fine of 10,000 dinars for a violation referred to in paragraph 1 of this Article shall be imposed on the responsible person within the legal person, or the representative of a legal entity.

\section{Conclusion}

Analysing the legislation, it can be concluded that the first general hypothesis has been confirmed: legislation (the legal framework in the Republic of Macedonia) regarding the inspection complies (is unified and harmonized) with the acts of the International Labour Organization and the directives of the European Union.

We can conclude that the penalties - fines in the laws of the three countries analyzed above are different, and that they are higher in R. Serbia and R. Croatia. Another observation is that in comparison with the Labor Law of the Republic Macedonia, where fines are in a fixed amount (e.g. 7.000 euros), their range in R. Serbia and R. Croatia is large (from-to). 
So, freedom is left to the misdemeanor authority to weigh the amount of the penalty, for example in R. Serbia from 6,500 to 16,260 euros, while in R. Croatia from 8200 to 13500 euro.

The general hypothesis is not confirmed that the legally determined amount of the misdemeanor penalties for violations of the regulations in the field of labor relations in compared countries is approximately the same

\section{References}

[1] Belovski, V, Kadriu, O, (2011). Komentar na zakonot za rabotnite odnosi, Izdavač: Kompanija Dr Belovski „Društvo za intelektualni uslugi i menadžment konsalting' - Skopje.

[2] Taken from Alen Supiot, (2010). Trudovo pravo, Publisher Ars Lamina DOO, 38-39.

[3] Pelissier, J., Supiot, A., Jeammaud, A., (2000). Droit du travail, Paris, 990.

[4] See article 47-53 of the Law on Misdemeanors (Off. Gazette of RMno.124/2015);

[5] Labor Law (consolidate text) Off. Gazette of R.Mno.167/2015;

[6] Labor Act of the Republic of Croatia from 2014;

[7] Labor Law of the Republic of Serbia (Official Gazette of RS no. 24/2005, $61 / 2005,54 / 2009.32 / 2013$ и 75/2014);

[8] http://www.mtsp.gov.mk/drzaveninspektorat-za-trud.nspx. 